Historic, archived document

Do not assume content reflects current scientific knowledge, policies, or practices. 

USDA FOREST SERVICE

RESEARCH PAPER INT-98

1971

\section{GRAZING POTENTIAL ON LODGEPOLE PINE CLEARCUTS IN MONTANA}

Joseph V. Basile and Chester E. Jensen

USS

INTERMOUNTAIN FOREST AND RANGE EXPERIMENT STATION Ogden, Utah 84401 



\section{GRAZING POTENTIAL ON LODGEPOLE PINE CLEARCUTS IN MONTANA}

Joseph V. Basile and Chester E. Jensen

INTERMOUNTAIN FOREST AND RANGE EXPERIMENT STATION

Forest Service

U.S. Department of Agriculture

Ogden, Utah 84401

Joseph F. Pechanec, Director 


\section{THE AUTHORS}

JOSEPH V. BASILE has been Associate Plant Ecologist on Intermountain Station's research work unit on Northern Rocky Mountain Grasslands, located in Bozeman, Montana, since 1963. Previously, he had been a member of a research unit on revegetation of big game ranges in southern Idaho, and had also served as a biologist with the Idaho Fish and Game Department.

CHESTER E. JENSEN is Principal Statistician for the Intermountain Forest and Range Experiment Station. Previously, he held the same position at the Northeastern and Central States Forest Experiment Stations. Mr. Jensen, who holds a master of forestry degree from Michigan State University, received his training in graduate statistics at Iowa State University. 


\section{CONTENTS}

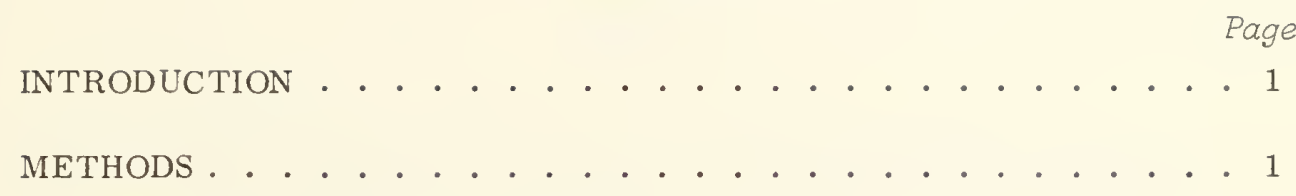

Field and Laboratory Methods . . . . . . . . . 1

Analysis . . . . . . . . . . . . . . 2

RESULTS AND DISCUSSION . . . . . . . . . . . . . 3

Time. . . . . . . . . . . . . . . . 3

Tree Factors . . . . . . . . . . . . . . 4 4

Site Index. . . . . . . . . . . . . . . 5

Topographic Factors. . . . . . . . . . . 6

Soil Factors . . . . . . . . . . . . 6

Forage Value . . . . . . . . . . . . . . 9

CONCLUSIONS . . . . . . . . . . . . . . . 10

LITERATURE CITED . . . . . . . . . . . . . . 11 


\section{ABSTRACT}

Clearcutting of lodgepole pine stimulates production of understory vegetation that may provide a grazing resource for livestock and big game for an estimated 20 years or more. Peak production of 800 to 1,000 lbs./acre occurred about 11 years after clearcutting. Prediction equations were developed to permit gross estimates of potential production and its change with time. Although palatability of the indigenous understory vegetation is low, the large acreages of lodgepole pine that are harvested annually warrant efforts to improve the quantity and quality of forage by reseeding. 


\section{Introduction}

Lodgepole pine (Pinus contorta Doug].) occupies 5.4 million acres in Montana (Wilson and Spencer 1967). This vast resource received limited commercial use until the early 1950's; since then, cutting for poles, pulp, and lumber has increased to an estimated 7,000 acres annually. ${ }^{1}$

Herbaceous growth develops after clearcutting and provides a potentially important grazing resource for approximately 20 years while the new timber stand is developing. Livestock and game animals now graze some clearcut areas, but the grazing potential appears to be considerably underutilized. This incomplete use is the result of several administrative factors, chief among which are a limited knowledge of the grazing resource, and a tendency to ignore it because of its transitory nature.

Efficient management of these ranges depends largely upon our ability to predict the expected composition, yield, and persistence of forage on clearcuts from selected environmental factors. Findings from a study aimed at providing the basis for prediction are presented here.

\section{Methods}

\section{FIELD AND LABORATORY METHODS}

This study was limited to unthinned, lower elevation (below 7,500 feet) clearcutand-burned areas in Montana, east of the Continental Divide. Twenty-five clearcut sites within the Lewis and Clark and the Gallatin National Forests were selected torepresent a range in post-clearcut ages ( 2 to 17 years had elapsed since cutting) and a variety of aspects.

On each of these sites, the percentage of aerial crown cover was estimated for each understory plant species within thirty circular plots which were $4.8 \mathrm{sq}$. $\mathrm{ft}$. in size and distributed in a random pattern over a l-acre macroplot. All herbaceous vegetation within the circular plots was clipped at ground level near the end of the growing season, dried at $60^{\circ} \mathrm{C}$. for 24 hours, and weighed. The center of each circular plot served also as the center of a milacre plot for data on tree regeneration.

Physical and chemical characteristics of the A and B soil horizons were determined from samples taken from two soil pits on each of the 25 sites.

We approximated site index for lodgepole pine for 19 of the 25 sampled sites from measures of site index, as described by Alexander (1966), on immediately adjacent, uncut stands that closely matched the clearcut areas in soils and topographic features.

\footnotetext{
${ }^{l}$ From files of USDA Forest Service, Northern Region, Missoula, Montana.
} 


\section{ANALYSIS}

Successive, full-screen, ${ }^{2}$ multiple regression sets enabled us to identify combinations of environmental factors that substantially affect forage production. Final acceptance of such combinations was conditioned by agreement of the algebraic signs of estimated effects with those of expected ${ }^{3}$ effects, under least squares fit. In these analyses, average dry weight in pounds (or yield) per acre was the dependent variable, and 37 environmental factors constituted the complete set of independent variables (listed below):

\section{A. Time (Number of Years Since Clearcutting) \\ B. Tree Factors (Regeneration):}

Density of Lodgepole Pine, determined by actual count

Density of All Trees, determined by actual count

Percent Canopy Cover of Lodgepole Pine

Percent Canopy Cover of All Trees

Stocking Rate of Lodgepole Pine, expressed as a percent of milacre plots in which a tree occurs

Stocking Rate of All Tree Species

Average Height of Lodgepole Pine Reproduction, estimated to nearest $1 / 2$ foot

Average Height of A11 Trees

C. Site Index

D. Topographic Factors:

Percent S1ope

Elevation

Cosine of Azimuth +1 , expressed in $2 \pi$ radians

Cosine of Azimuth +sine azimuth +2 , expressed in $2 \pi$ radians

E. Soiz Factors:

Each of the following represents two variables, one for the A horizon and one for the B horizon:

Field Capacity, estimated by moisture retention at $1 / 3$-atmosphere of pressure, using standard pressure membrane apparatus and procedures outlined by Richards (1954).

${ }^{2}$ The dependent variable is fitted as a function of each of all combinations of specified groups of independent variables via computer. $R^{2}$, the Coefficient of Determination, is printed out for each regression.

"Expected" from prior knowledge. 
Wilting Point, estimated by moisture retention at 15-atmospheres of pressure, using standard pressure plate apparatus.

Percent Sand, determined by hydrometer method.

Percent Silt, determined by hydrometer method.

Percent Clay, determined by hydrometer method.

Available Potassium, determined by flame photometer.

Percent Organic Matter, measured by Walkely-Black wet digestion chromic acid method (Jackson 1958).

Total Nitrogen, measured by the micro-Kjeldahl method, using $\mathrm{CuSO}_{4}$ and $\mathrm{Na}_{2} \mathrm{SO}_{4}$ digestion mixture.

Bulk Density, measured by the paraffin coating technique.

Soil Reaction, or $\mathrm{pH}$, measured with a glass electrode in a saturated paste.

Horizon Thickness, measured in the field.

Water Holding Capacity, estimated by the difference between field capacity and wilting point, and weighted by horizon thickness, rock content, and percent fine material.

\section{Results and Discussion}

Understory yields ranged from about 100 to 1,200 1bs./acre (dry weight), and averaged 644 lbs./acre.

\section{TIME}

Understory production is expected to be low, both immediately after logging and after canopy closure of the reproducing lodgepole pine stand. Between these two points in time, production should peak. This trend was strongly evident within the 17-year age span of the plots, and was approximated by the sigmoid function, $e^{-k}$, where $\mathrm{e}=2.718$ and $\mathrm{k}=0.01667$ (age of cut minus age at peak production) ${ }^{2}$. So the time effect was retained as a component of all models examined.

Total understory production reached its peak about 11 years after clearcutting. The several vegetal classes, however, performed differently with time (fig. 1). Sedge was the only class that showed no discernible pattern; its mean is shown in figure 1. The regression for grasses was not significant ( $P>.05)$, but the data suggest slight peaking at about 13 years. The regressions for forbs and shrubs were significant $(\mathrm{P}<.05)$. Forb production peaked at 10 years. Shrub production increased over the entire range of time, but the increase was slower after 11 years than it was previously, and there is a slight but unconfirmed hint of a flattening of production at about 15 or 16 years after clearcutting. These production patterns were determined on sites supporting unthinned lodgepole pine reproduction. Observations in other clearcuts where reproduction had been thinned suggest that thinning may delay the peaking of understory production a few years. If this is true, a grazing potential of perhaps 20 years, or more, may be expected on clearcuts where tree regeneration is thinned. 


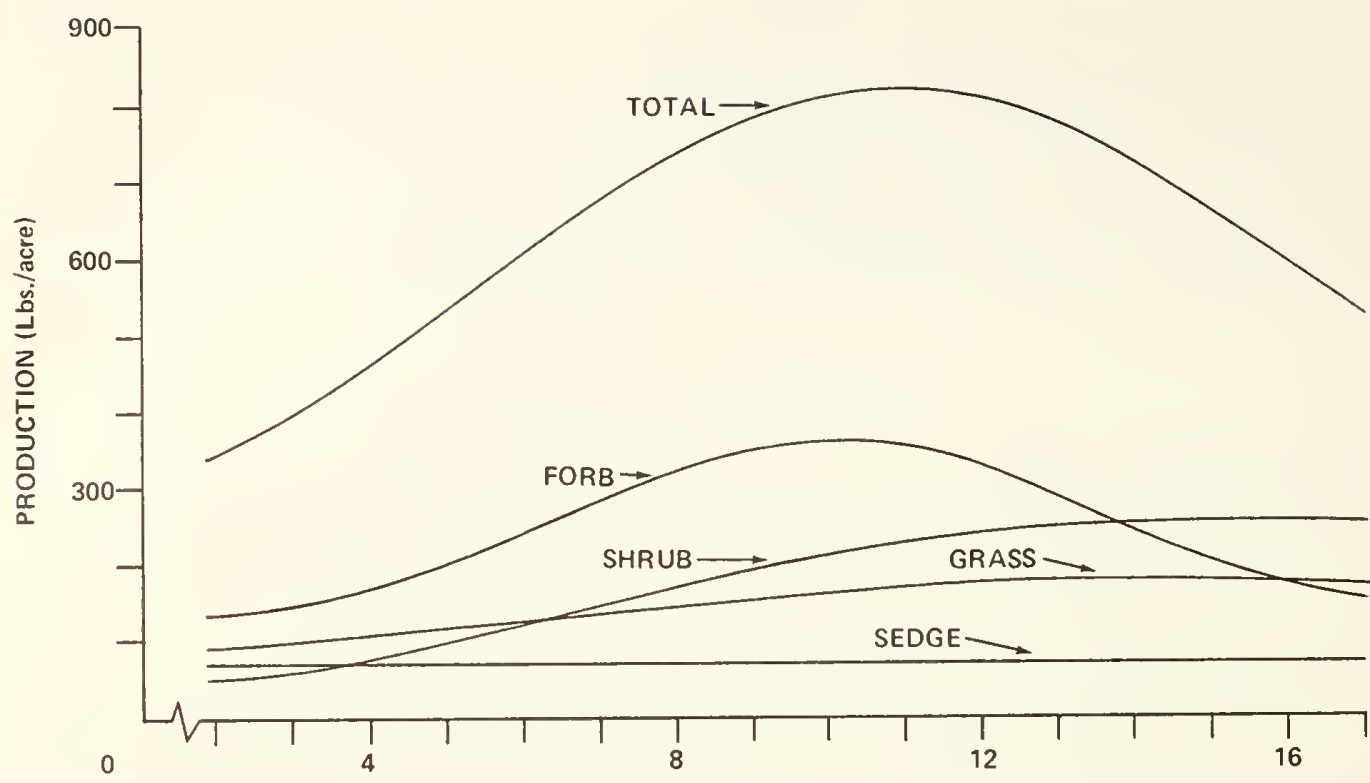

YEARS SINCE CLEARCUTTING

Figure 1.--Trends in understory production on lodgepole pine clearcuts as affected by time.

The concurrent increase in shrub production and decrease in herbaceous plants is attributed to grouse whortleberry (Vaccinium scoparium) which constituted about one-half of the shrub cover on these sites. The roots of grouse whortleberry lie mostly within 2 or 3 inches of the soil surface. This soil zone is freer of roots of the other vegetation than are the deeper zones; also, it is often the sole recipient of moisture from light summer rains. The competitive advantage thus accorded grouse whortleberry enables it to prosper at the expense of the other understory plants.

Except for scattered individuals of other shrub species, grouse whortleberry is often the sole shrub in older stands of lodgepole, where it often dominates the understory.

\section{TREE FACTORS}

Tree regeneration variables are highly unstable quantities for a few years after clearcutting; thus, they are of limited usefulness for predicting yields of understory vegetation. They are of interest, however, because they do affect these yields.

The general trend of production with time conforms to expectation. As tree canopies thicken and root systems expand, understory vegetation succumbs to the increasing competition for light and moisture, as evidenced by the usual paucity of understory plants in overstocked stands of lodgepole pine that are at the sapling-or-older stage of development. 


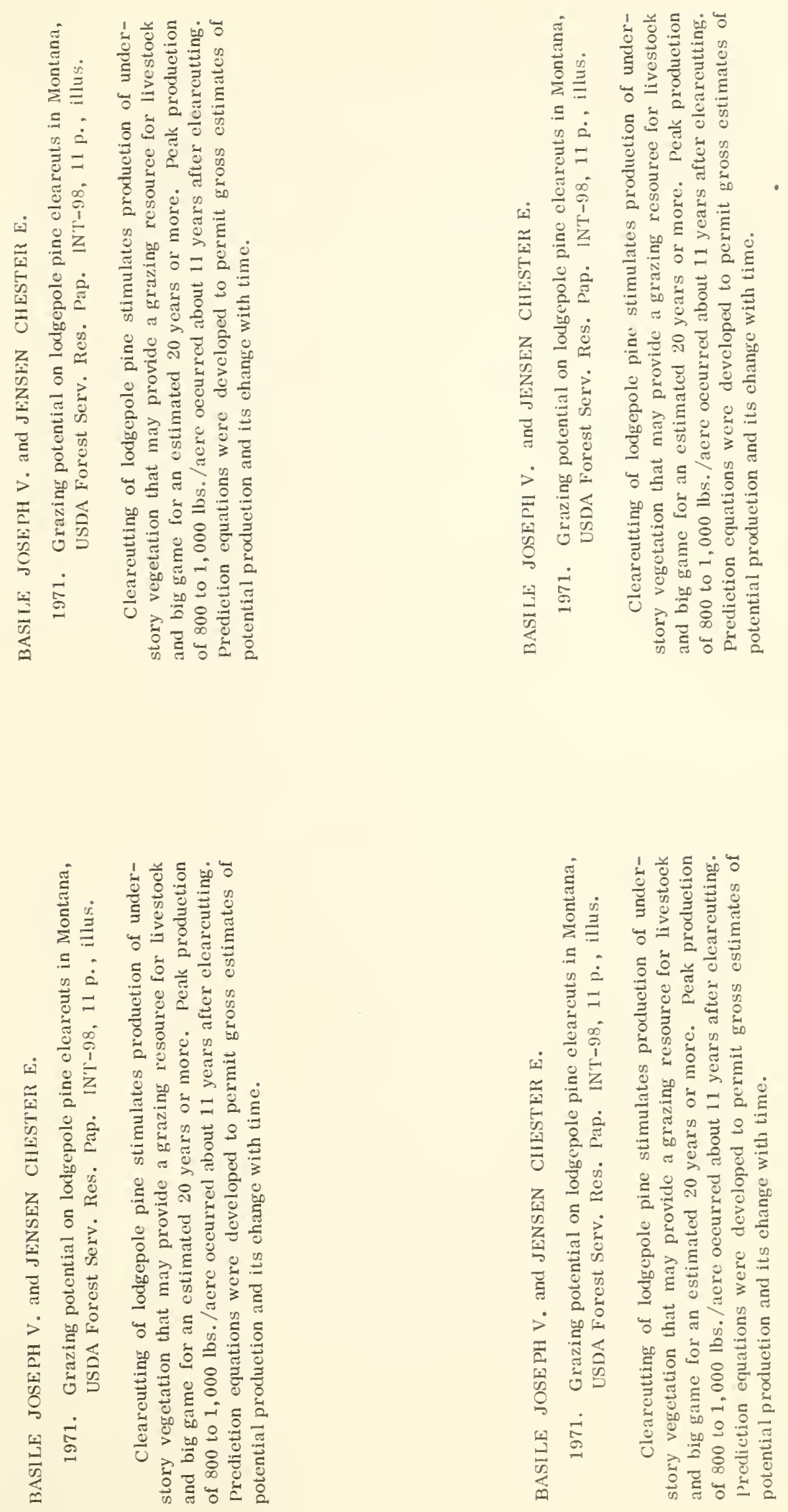

In this study, lodgepole regeneration reached the early sapling stage on only three clearcuts, the youngest of which was 14 years old. Herbage yields, however, started to decline on 10 - and 11-year-old clearcuts where tree heights averaged only 2 feet. Apparently, then, lodgepole pine adversely affects herbaceous plants while still in the seedling stage. Moreover, we believe competition for light was negligible on the sampled sites because the maximum tree canopy cover was only 37 percent and averaged a mere 7 percent. After discounting the time effect, tree canopy and understory yield were not significantly correlated.

Very likely the roots of seedling trees had developed sufficiently by 10 years of age to gain a competitive advantage over herbaceous plants for available moisture. Horton (1958) reported that open-grown lodgepole exhibited about a 1:1 ratio of maximum lateral root length to stem height for the first 20 years. If the $1: 1$ ratio applies to trees in this study, in which stem heights averaged 2 feet, roots should have radiated as far as 2 feet from the stem. Because lodgepole pine density averaged 5,800 stems per acre, then uniformly distributed trees would be spaced about 33 inches apart. Thus, the roots of a given tree would overlap those of its immediate neighbors by about 1 foot. Apparently, then, we could apply to our study sites Horton's statement that "in a fully-stocked condition, all of the available rooting space is presumably utilized so that a complex interweaving network of roots occurs." Also, we could assume that this network of tree roots would compete effectively with understory plants for soil moisture.

Of course, trees were not uniformly distributed on the clearcut sites, but the added effect of stocking rates on accountable variation in forage yields was sufficiently high to suggest considerable overlapping of root systems:

$$
\begin{array}{rc}
\text { yield }=f(\text { time }) & \frac{R^{2}}{2.38} \\
\text { yield }=f(\text { time }+\% \text { stocking of lodgepole }) & .47 \\
\text { yield }=f(\text { time }+\% \text { stocking of all trees }) & .55
\end{array}
$$

Further additions of tree density or of tree canopy cover, or both, failed to raise $\mathrm{R}^{2}$ above 0.56 .

\section{SITE INDEX}

Ideally, a prediction model should be based on variables for which measurements are easily obtained. Accordingly, we examined the suitability of site index for predicting understory yield. For this prediction, we used data from the 19 clearcuts for which site index could be approximated from the immediately adjacent uncut stands.

After fitting the time effect, site index accounted for 1 percent of the variation in yield. As an additive or interacting term with additional variables in the model, the contribution of site index to accountable variation was still too small to warrant its retention in prediction models. Apparently this measure of site potential for tree growth was not closely related to the production of associated understory vegetation. 


\section{TOPOGRAPHIC FACTORS}

As sole additive components to the "yield = $f$ (time)" equation, slope accounted for an additional 20 percent of the variation, elevation for 11 percent, and aspect for less than 1 percent.

This response to slope is interesting. One usually finds increasing slope steepness associated with shallower and rockier soils and greater runoff, and therefore with decreasing herbage production; but in this study, contrary to expectations, understory production responded positively to slope. In addition, the data revealed a strong coincidence of the higher slope values with the more moist sites whose expected influence on yield is positive. This confounding of slope with other variables cast doubt on the validity of using slope for predictive purposes in other areas; thus, it was eliminated from further consideration.

The remaining topographic variables, elevation and aspect, were added to the "yield $=f$ (time)" equation and this resulted in $\mathrm{R}^{2}$ values as follows:

$$
\begin{array}{ll}
\text { yield }=f(\text { time }) & 0.38 \\
\text { yield }=f(\text { time }+ \text { elevation }) & .49 \\
\text { yield }=f(\text { time }+ \text { elevation }+ \text { aspect }) & .51
\end{array}
$$

When added to more complex models, elevation did not contribute sufficiently to $\mathrm{R}^{2}$ values to warrant its retention.

The effect of aspect was tested two ways: as cosine azimuth +1 , which places minimum expected yields at due south; and as cosine azimuth + sine azimuth +2 , which places minimum expected yields at southwest. Discounting the time effect, neither of these components contributed materially (less than 2 percent) to accountable variation.

\section{SOIL FACTORS}

The influence of moisture on understory production was emphasized by the additive contribution of field capacity of the A and B horizons to the "yield = $f$ (time)" equation, with $\mathrm{R}^{2}=0.74$. The further addition of sand content of the $\mathrm{A}$ horizon, another moisture-related variable, produced the equation

$$
\begin{aligned}
\text { Yield }= & -251.4000+383.5379 \mathrm{e}^{-\frac{(1-11)^{2}}{60}}+3.1646 \mathrm{FC}_{\mathrm{A}} \\
& +16.8020 \mathrm{FC}_{\mathrm{B}}+291.7550 \mathrm{e}^{-\frac{\mid \text { sand }_{\mathrm{A}}-\left.55\right|^{2.5}}{1,200}}
\end{aligned}
$$

with $\mathrm{R}^{2}=0.79$. Contributions of other soil variables added to this model were negligible. 
Wilting point could be substituted for field capacity in this and in alternative models with little sacrifice in $\mathrm{R}^{2}$ values. However, the addition of wilting point did not improve any model containing field capacity.

Available potassium $(K)$ in the soil solum ranked second only to the field capacity and wilting point variables in degree of correlation with understory yields, and produced an $\mathrm{R}^{2}$ of 0.73 when added to the "yield $=f$ (time)" equation. The further additions of sand content of the $A$ and $B$ horizons raised the $R^{2}$ to 0.81 . However, equally satisfactory results were obtained with the potassium and sand values of the $B$ horizon only:

$$
\begin{array}{rr}
\text { yield }=f(\text { time }) & \frac{\mathrm{R}^{2}}{} \\
\text { yield }=f\left(\text { time }^{2} K_{B}\right) & .70 \\
\text { yield }=f\left(\text { time }+K_{B}+\text { Sand }_{B}\right) & .80
\end{array}
$$

as in the equation

$$
\begin{aligned}
\text { Yield }= & -228.051+588.614 \mathrm{e}^{-\frac{(\mathrm{T}-11)^{2}}{60}}+1.702 \mathrm{~K}_{\mathrm{B}} \\
& +282.783 \mathrm{e}^{-\frac{\left|\mathrm{Sand}_{\mathrm{B}}-55\right| 2.5}{1,200}}
\end{aligned}
$$

Holmes and Tackle (1962) found exchangeable potassium in the B horizons to be noncorrelated with heights of dominant lodgepole pine trees $(r=0.055)$. In this study, potassium in the B horizon was not significantly correlated with site index for lodgepole pine $(r=0.37)$, but potassium in the A horizon was significantly correlated $(\mathrm{P}<.05)$ with site index $(r=0.46)$. A modest correlation with site index plus a marked effect on understory yields suggests that fertilizing with potassium may be beneficial both to understory production and to growth rates of lodgepole pine.

The two above equations may serve as interim predictors of understory yield. The response surfaces of these equations over the full ranges of time and sand content are shown in figures 2 and 3 for the extremes of field capacity and of potassium, respectively. In both instances, the change between surfaces is linear between the two extremes shown for the third independent variable. Being additive, the models may not fit too well near the left edge of the surfaces, since the expectation would be for these to come closer together near time 0 . Nonetheless, they do emphasize the substantial effect of field capacity and of potassium on understory yields. 


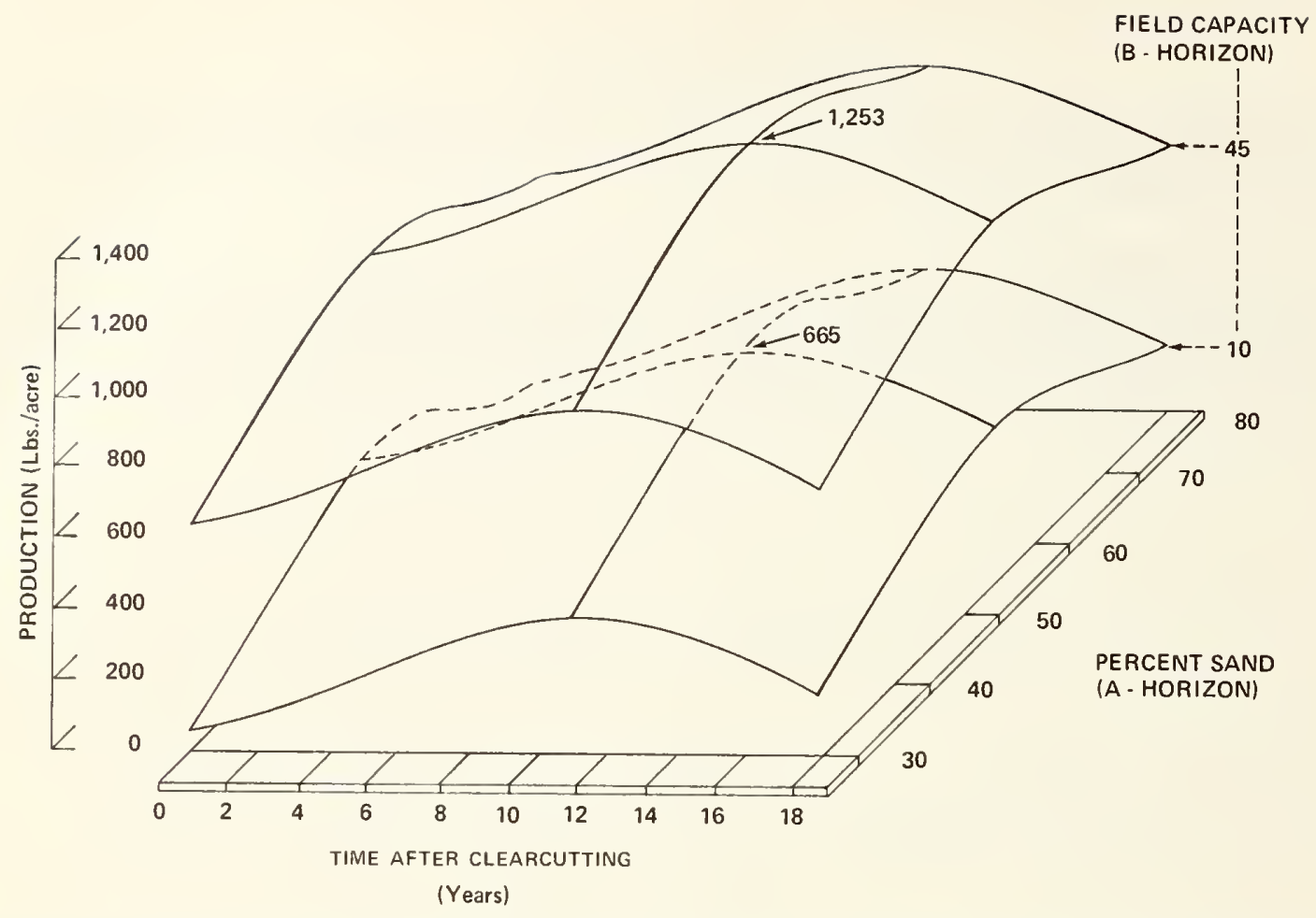

Figure 2.--Response surfaces at extremes of field capacity, showing the relations between understory production, time after clearcutting, and percent sand.

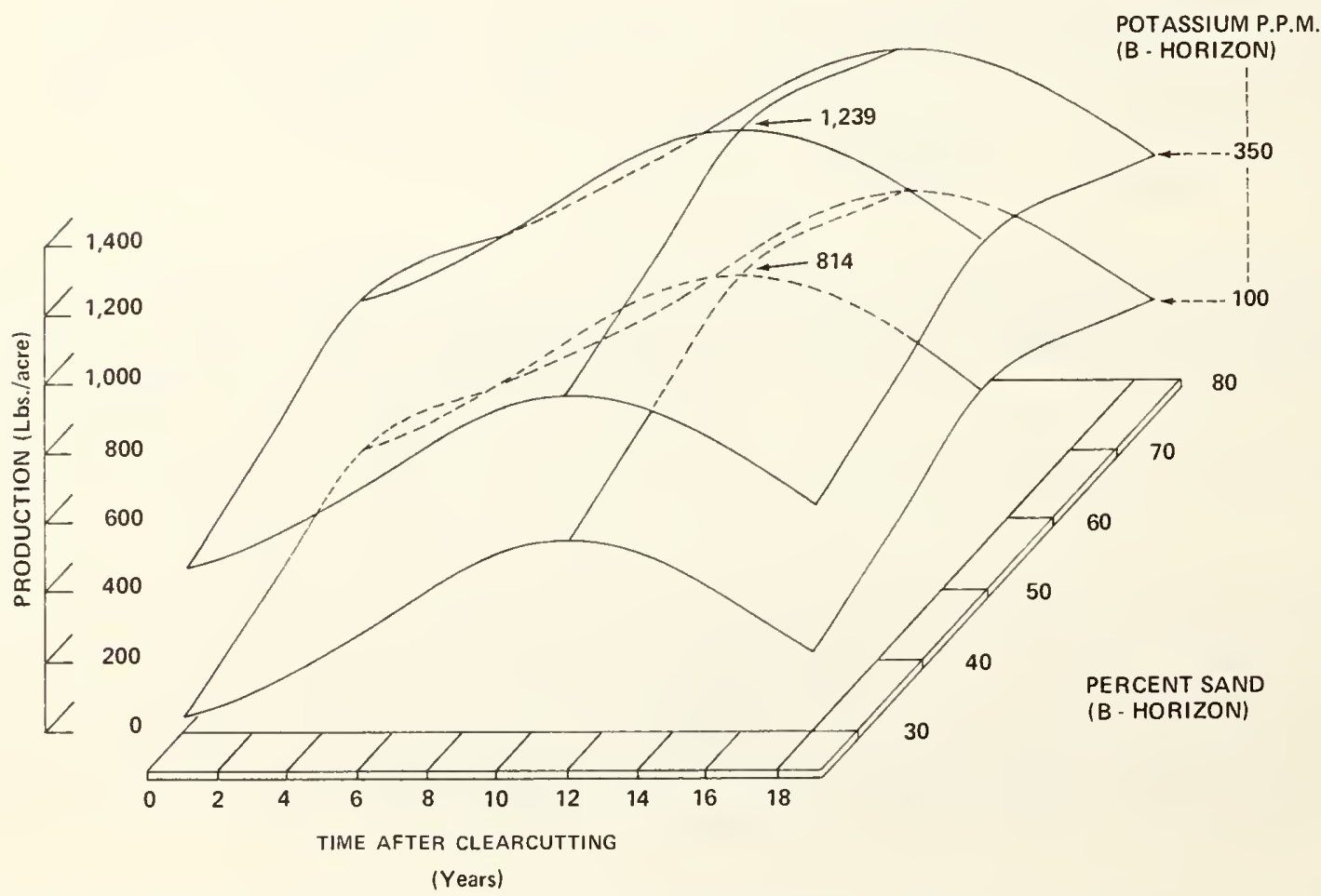

Figure 3.--Response surfaces at extremes of potassium content, showing the relations between understory production, time after clearcutting, and percent sand. 


\section{FORAGE VALUE}

Major species of the understory vegetation are given in table 1 . We computed species composition on each site from percentage aerial crown cover. Separate palatability ratings for cattle, sheep, and elk were assigned to each of the species that contributed 3 percent, or more, to the cover on at least one site. Ratings ranged from 0 to 6 , with a 0 rating for unpalatable plants and a 6 rating for excellent species. Species contributing less than 3 percent of the cover were arbitrarily rated 3 , about midway in the scale. Sources consulted for information on palatability included Dayton (1960), Hayes and Garrison (1960), Hermann (1966), and USDA Forest Service (1937).

Table 1.--Composition, aerial crown cover, and frequency of vegetation on lodgepole pine clearcuts. Includes only those species contributing 3 percent or more to the vegetal cover on at least one site and occurring on at least 4 of the 25 sompled sites

\begin{tabular}{lll}
\hline \multirow{2}{*}{ Species } & $\vdots$ No. of & $\%$ Frequency $: \%$ Composition $: \%$ Aerial cover \\
\hline
\end{tabular}

$\underline{\text { FORBS }}$

\begin{tabular}{|c|c|c|c|c|c|c|c|}
\hline Antennaria racemosa & 16 & 22 & $3-53$ & 2 & $\operatorname{Tr}-6$ & 1 & $\operatorname{Tr}-2$ \\
\hline Amica cordifolia & 23 & 64 & $13-100$ & 7 & $1-24$ & 2 & $\operatorname{Tr}-9$ \\
\hline Aster spp. & 22 & 37 & $3-100$ & 6 & $\operatorname{Tr}-23$ & 2 & $\operatorname{Tr}-11$ \\
\hline Epizobium angustifolium & 22 & 47 & $3-100$ & 9 & $\operatorname{Tr}-26$ & 3 & $\operatorname{Tr}-9$ \\
\hline Erigeron spp. & 5 & 19 & $7-37$ & 2 & $\operatorname{Tr}-6$ & 1 & $\operatorname{Tr}-2$ \\
\hline Emythronium grandiflomm & 9 & 41 & $7-97$ & 1 & $\operatorname{Tr}-5$ & $\operatorname{Tr}$ & $\operatorname{Tr}-1$ \\
\hline Eragaria spp. & 20 & 22 & $3-67$ & 3 & $\operatorname{Tr}-12$ & 1 & $\operatorname{Tr}-5$ \\
\hline Galizon boreale & 7 & 20 & $3-80$ & 1 & $\operatorname{Tr}-6$ & $\operatorname{Tr}$ & $\operatorname{Tr}-3$ \\
\hline Hieracium cynoglossoides & 24 & 42 & $3-83$ & 2 & $\operatorname{Tr}-7$ & $\operatorname{Tr}$ & $\operatorname{Tr}-2$ \\
\hline Heuchera cylindrica & 7 & 10 & $3-40$ & 1 & $\operatorname{Tr}-5$ & $\operatorname{Tr}$ & $\operatorname{Tr}-1$ \\
\hline Linnaea borealis & 5 & 29 & $3-60$ & 3 & $\operatorname{Tr}-8$ & 2 & $\operatorname{Tr}-4$ \\
\hline Lupinus spp. & 24 & 47 & $3-97$ & 10 & $\operatorname{Tr}-38$ & 4 & $\operatorname{Tr}-20$ \\
\hline Taraxacum officinale & 20 & 17 & $3-53$ & 1 & $\operatorname{Tr}-3$ & $\operatorname{Tr}$ & $\operatorname{Tr}-2$ \\
\hline Thalictmon mierale & 5 & 16 & $3-43$ & 3 & $\operatorname{Tr}-7$ & 1 & $\operatorname{Tr}-3$ \\
\hline \multicolumn{8}{|l|}{ RASSES AND SEDGE } \\
\hline Carex geyeri & 25 & 63 & $37-93$ & 10 & $2-42$ & 3 & $\operatorname{Tr}-9$ \\
\hline Agrostis spp. & 14 & 24 & $3-53$ & 3 & $\operatorname{Tr}-14$ & 1 & $\operatorname{Tr}-11$ \\
\hline Calomagrostis mbescens & 14 & 69 & $7-100$ & 15 & $\operatorname{Tr}-36$ & 5 & $\operatorname{Tr}-12$ \\
\hline Calomagrostis spp. & 7 & 15 & $3-70$ & 5 & TR-16 & 2 & $\operatorname{Tr}-7$ \\
\hline Phleum pratense & 4 & 22 & $3-50$ & 2 & $\operatorname{Tr}-4$ & $\operatorname{Tr}$ & $\operatorname{Tr}-2$ \\
\hline Trisetum spicatum & 16 & 34 & $3-90$ & 2 & $\operatorname{Tr}-5$ & 1 & $\operatorname{Tr}-2$ \\
\hline
\end{tabular}

TREES AND SHRUBS

Arctostaphylos uva-ursi Junipemis communis

7

Rosa spp.

$\begin{array}{rcr}19 & 3-50 & 4 \\ 10 & 3-23 & 3 \\ 29 & 3-70 & 2 \\ 52 & 7-87 & 7 \\ 74 & 30-100 & 18\end{array}$
$\operatorname{Tr}-17$
Tr -10
$\operatorname{Tr}-5$
1-17
2-36

Tr -4

Tr-4

Tr-2

Tr -7

Tr -17 
The percent composition of each understory species was multiplied by its palatability rating, and the sum of these resultant products was divided by 100 to arrive at an average palatability rating for all understory vegetation. Based on the 0 to 6 scale, average palatability ratings were approximately 1.7 for cattle, 2.0 for sheep, and 2.4 for elk--in other words, fair for cattle and sheep, and only slightly better for elk. Because of the widespread occurrence and appreciable amounts of lupine on clearcut areas, sheep grazing might be hazardous .

\section{Conclusions}

Clearcutting, and thinning of subsequent lodgepole pine regeneration, stimulates forage production that may provide a grazing resource for livestock and big game for an estimated 20 years or more. A harvest of 10,000 acres/year of lodgepole pine in Montana appears probable in the near future. Thus, the lodgepole pine type represents a grazing potential of nearly $1 / 4$ million acres on a sustained basis. This impressive grazing potential warrants an upgrading of the less impressive yields (average peak production was about 800-1,000 lbs./acre) and palatability (fair) of the indigenous plant cover. For purposes of such upgrading, it is desirable to conduct seeding studies on ways to increase forage yields and palatability without adversely affecting timber management objectives.

Where indigenous vegetation is to be grazed, gross estimates of potential production, and its change over a period of time, are possible with the interim prediction equations presented here. These estimates permit an appraisal of grazing potentials in advance of timber cutting and probably will allow better integration of grazing use on clearcuts with that on permanent range.

If seeding of clearcuts is contemplated, the prediction equations will be helpful in the judicious allocation of monies to those sites offering maximum returns on investment. 


\section{Literature Cited}

Alexander, Robert R.

1966. Site indexes for lodgepole pine, with corrections for stand density:

instructions for field use. U.S. Forest Serv. Res. Pap. RM-24, 7 p.

Dayton, William A.

1960 Notes on western range forbs: Equisetaceae through Fumariaceae. USDA Handbook 161, 254 p., illus.

Hayes, Doris W., and George A. Garrison

1960. Key to important woody plants of eastern Oregon and Washington. USDA Handbook 148, 227 p., illus.

Hermann, F. J .

1966. Notes on western range forbs: Cruciferae through Compositae. USDA Handbook 293, 365 p., illus.

Holmes, John R. B., and David Tackle

1962. Height growth of lodgepole pine in Montana: related to soil and stand factors. Mont. Forest \& Conserv. Exp. Sta., Sch. Forestry, Mont. State Univ., Missoula, Bull. 21, 12 p., illus.

Horton, K. W.

1958. Rooting habits of lodgepole pine. Can. Dep. Northern Aff. \& Nat. Resources Forestry Br., Forest Res. Div., Tech. Note 67, 26 p.

Jackson, M. L.

1958. Soil chemical analysis. Vol. XIV, 498 p. Englewood Cliffs, N. J.: Prentice-Hall, Inc.

Richards, L. A.

1954. Diagnosis and improvement of saline and alkali soils. USDA Handbook 60, 160 p., illus.

USDA Forest Service

1937. Range plant handbook. 842 p., illus.

Wilson, Alvin K., and John S. Spencer, Jr.

1967. Timber resources and industries in the Rocky Mountain States. U.S.

Forest Serv. Resource Bul1. INT-7, 67 p., illus. 

Headquarters for the Intermountain Forest and Range Experiment Station are in Ogden, Utah. Field Research Work Units are maintained in:

Boise, Idaho

Bozeman, Montana (in cooperation with Montana State University)

Logan, Utah (in cooperation with Utah State University)

Missoula, Montana (in cooperation with University of Montana)

Moscow, Idaho (in cooperation with the University of Idaho)

Provo, Utah(in cooperation with Brigham Young University) 
